\title{
RESPON TANAMAN MENTIMUN (CUCUMIS SATIVUS L) TERHADAP PESTISIDA NABATI DAN PUPUK CAIR GREEN TONIC
}

\section{Response of Cucumber (Cucumis sativus L) Plant of Vegetable Pesticides and Green Tonic Liquid Fertilizers}

\author{
Mangsur Efendi ${ }^{1}$, Oktarina $^{2)}$, Insan Wijaya ${ }^{3)}$ \\ Prodi Agroteknologi Fakultas Peranian UM Jember \\ e-mail : ${ }^{1)}$ mangsurefendi@yahoo.com, ${ }^{2}$ oktarina@unmuhjember.ac.id, \\ ${ }^{3)}$ insan.wijaya@unmuhjember.ac.id
}

\begin{abstract}
ABSTRAK
Penelitian ini bertujuan untuk mengetahui; (1) Jenis bahan pestisida nabati yang tepat terhadap pertumbuhan, hasil dan intensitas serangan OPT tanaman mentimun. (2) Waktu pemupukan pupuk cair green tonic yang tepat terhadap pertumbuhan dan hasil tanaman mentimun. (3). Interaksi antara jenis bahan pestisida nabati dengan waktu pemupukan pupuk cair green tonic yang tepat terhadap pertumbuhan, hasil dan intensitas serangan OPT tanaman mentimun. Penelitian dilakukan dengan pola dasar Rancangan Acak Kelompok Lengkap (RAKL) dengan dua faktor yaitu faktor 1 : jenis bahan pestisida nabati, yaitu: P0: tanpa pestisida, P1: Ekstrak Daun Pepaya, P2: Ekstrak Daun Lamtoro, P3: Campuran Ekstrak Daun Pepaya dan Ekstrak Daun Lamtoro (1: 1) dan Faktor 2 : waktu pemberian pupuk cair tonik hijau G1: Tampa Green Toninc, G2: 7 dan 14 hst, G3: 14 dan 28 hst, diulang 3 kali. Hasil menunjukkan bahwa pestisida nabati berpengaruh terhadap pertumbuhan, hasil dan intensitas serangan OPT. Jenis campuran Ekstrak Daun Pepaya dan Ekstrak Daun Lamtoro (P3) memberikan pengaruh terbaik. Pupuk cair green tonik (G3 pada 14 dan $28 \mathrm{hst}$ ) memberikan yang terbaik.
\end{abstract}

Kata kunci: pestisida nabati, Pupuk Cair Green Tonic, Tanaman Mentimun.

\section{ABSTRACT}

The research aims: (1) Type of appropriate vegetable pesticide material against the growth, yield and intensity of the attack of the cucumber plant. (2) Time fertilization of liquid fertilizer green tonic is appropriate to the growth and yield of cucumber crops. (3). Interaction between kinds of vegetable pesticide material with time fertilization of liquid fertilizer green tonic is appropriate to the growth, yield and intensity of the attack of the cucumber crop. The research was conducted with the Random Complet Block Design (RCBD) with two factors. The first factor: type of vegetable pesticide; P0: Control, P1: Papaya leaf extract, P2: Lamtoro leaf extract, P3: Papaya leaf extract and leaf extract mixture Lamtoro (1:1) and factor 2th: time-giving green tonic liquid fertilizer G1: Not Green Toninc, G2:7 and 14 HST, G3:14 and 28 HST, repeated 3 times. Results show that vegetable pesticides affect the growth, outcome and intensity of OPT attacks. The mixture of papaya leaf extract and Lamtoro leaf extract (P3) gives you the best influence. Green Tonic Liquid Fertilizer (G3 at 14 and 28 HST) gives the best.

Keywords : Vegetable Pesticides, Giving Green Tonic Liquid Fertilizers, Cucumber Plants.

\section{PENDAHULUAN}

Mentimun (Cucumis sativus L.) merupakan tanaman holtikultura dari suku labulabuan (Cucubitaceae) yang sudah populer di dunia. (Sumpena, 2001). Mentimun menghasilkan buah yang dapat dimakan, selain itu. kandungan gizi yang terdapat pada 
mentimun adalah protein, lemak, karbohidrat, kalsium, fospor, besi, vitamin A, C, B1, B2, B6, air, kalium, natrium. Mentimun memiliki khasiat, salah satunya adalah menurunkan tekanan darah (Rukmana, 1994).

Upaya pengembangan budidaya mentimun mempunyai beberapa kendala diantaranya adalah serangan organisme pengganggu Tanaman (OPT) yang menjadi hama dan penyakit mentimun.. (Rukmana, 1994).

Beberapa jenis hama dan penyakit yang menyerang tanaman mentimun diantaranya : 1) Ulat daun (Diaphania indica). Larva berwarna hijau gelap dengan dua garis putih sepanjang tubuh (Brown 2003). Larva memakan daun, batang muda yang lunak dan dapat menggerak buah.dan buah menjadi cepat busuk (Cabi, 2005). 2) Kutu daun Aphis gossypii Clover (Hemiptera: Aphididae). Kutu daun berukuran 1-2 mm, berwarna kuning atau kuning kemerahan atau hijau gelap sampai hitam. Geja;a yang ditimbulkan kutu daun adalah daun keriput, keriting dan menggulung, selain itu kutu ini merupakan vector virus (Mossler et al, 2007). 3). Penyakit layu disebabkan jamur Fusarium oxysporum, bakteri oleh Erwinia tracheiphila dan nematoda Meloidogyne sp. (CABI 2005)

Pengendalian OPT menggunakan bahan kimia tentu mempunyai dampak negatif. Terjadinya peledakan hama baru, penumpukan residu bahan kimia di dalam tanah dan hasil panen, matinya musuh alami, pencemaran lingkungan oleh residu bahan kimia, dan kecelakaan bagi pengguna. Oleh karena itu perlu dicari cara pengendalian OPT yang lebih aman dan ramah lingkungan (Anonim 2012a).

Pestisida yang ramah lingkungan diantaranya menggunakan tanaman pepaya(Carica papaya L) dan lamtoro (Leucaena leucocephala). Daun Pepaya mengandung senyawa metabolit sekunder berupa papain, carposide . Senyawa ini efektif untuk mengendalikan hama larva dan hama penghisap" (Anonim 2013c).

Lamtoro merupakan tanaman perdu pohon yang mengandung senyawa berupa alkoloid, saponin, flavonoid, triterpenoid, mimosi, leukunin, protein, lemak, kalsium, fosfor, besi, vitamiin A dan vitamin B. Daun lamtoro memiliki kandungan asam amino yang dapat larut dalam air yang di sebut leucinol (Hodiyah, 2015).

Selain kendala hama, budidaya timun juga memerlukan nutri yang baik sehingga pertumbuhan produksi bisa meningkat. Pupuk organik yang komersil sudah banyak yang dijual di pasaran, diantaranya adalah Pupuk cair Green Tonic 
Pupuk cair Green Tonic adalah pupuk pelengkap yang mengandung unsur hara makro dan unsur hara mikro serta kandungan protein, lemat dan zat-zat organik. Kandungan nitrogen dalam pupuk cair berperan sebagai penyusun protein sedangkan fosfor dan kalsium berperan dalam memacu pembelahan jaringan meristem dan merangsang pertumbuhan akar (Rahmi,dkk.,2007).

Berdasarkan hasil penelitian menunjukkan bahwa dengan perlakuan pupuk cair green tonic terjadi penambahan jumlah akar 15 kali lipat (Marschel, 1995). Selain itu, pupuk green tonic mengandung unsur kalium dan kalsium yang diduga akan meningkatkan pertumbuhan dan perkembangan akar lateral sehingga mampu meningkatkan jumlah akar.

Pupuk cair Green Tonic mengandung : Unsur makro ( N 14,73\%, P205 1,5\%, K20 2,55\%, S 0,33\%), unsur mikro (Ca 1,33\%, Mg 0,02\%, B 615,63 ppm, Cu 2,25 ppm, Mn 17,18 ppm, Cd 0,59 ppm, Zn 111,77 ppm, Fe 706,38 ppm) dan senyawa organik : Protein $70,32 \%$, Lemak 1,18\%, Zat-zat organik 1,55\% ( Cv. Yan utama corporation Green Tonic).

Pupuk cait green tonic dapat mempercepat tumbuhnya tanaman, merangsang tumbuhnya flora dari tanaman yang baru muncul, menambah jumlah anakan, membuat tanaman cepet berbunga dan berbuah., menyuburkan tanaman, terutama pada keseluruhan daun sehingga dapat membuat tanaman menjadi lebih sehat, dan berwarna hijau segar, mencegah daun, bunga dan buah dari kelayuan dan kerontokan.(cv. Yan utama corporation.).

Strategi pengendalian hama dan penyakit yang tepat dengan menggunakan pestisida nabati daun pepaya dan lamtoro secara sendiri ataupun campuran yang dikombinasikan dengan pupuk cair organik green Tonic diharapkan dapat menekan serangan OPT dan meningkatkan pertumbuhan dan hasil tanaman mentimun.

\section{METODE PENELITIAN}

Penelitian dilaksanakan di lahan percobaan Fakultas Pertanian Univesitas Muhammadiyah Jember, Jl. Karimata 49 Kabupaten Jember mulai bulan Februari sampai Maret 2018.

Penelitian ini dilakukan secara faktorial dengan rancangan acak kelompok Lengkap (RAKL) yang terdiri dari 2 faktor. Faktor pertama pestisida nabati (P). yang terdiri dari 4 level yaitu : P0= tanpa pestisida, P1 = Ekstrak Daun Pepaya, P2 
= Ekstrak Daun Lamtoro; P3 = Campuran Ekstrak Daun Pepaya dan Ekstrak Daun Lamtoro (1:1) Faktor kedua waktu pemberian pupuk cair green tonic $(G)$ G1 = Tanpa pestisida (Tampa Green Toninc), G2 = 7 Hari dan 14 hari, G3 = 14 dan 28 hst. Sehingga diperoleh 12 satuan percobaan yang masing-masing diulang 3 kali.

Varibael Pengamatan meliputi : 1) Tinggi Tanaman (cm), diamati mulai umur 2 minggu hst dan diamati setiap 1 minggu sekali. 2) Mulai berbunga, diamati saat mentimun berbungan 50\% dari tanaman tersebut. 3) Jumlah Buah total pertanaman, pengamatan dilakukan pada panen pertama sampai dengan panen kelima. 4) Panjang Buah (cm), diukur pada pada buah, dengan cara mengukur dari mulai pangkal buah sampai ujung buah. Pengamatan dilakukan pada panen pertama sampai dengan panen kelima. 5) Berat Buah dengan menimbang dari panen pertama sampai panen kelima. 6) Diameter buah $(\mathrm{cm})$, dilakukan dengan mengukur menggunakan jangka sorong, mulai panen pertama sampai panen kelima. 7) Jumlah buah sehat per tanaman dihitung dari awal panen sampai panen ke lima. 8) Intensitas tanaman yang terserang dihitung pada 7, 14, 28, hst sampai panen, dengan menggunakan rumus:

$$
\mathbf{P}=\frac{\sum n x v}{Z \times N} \times 100 \%
$$

Keterangan :

$\mathrm{P}=$ Intensitas tanaman terserang $(\%)$

$\mathrm{v}=$ nilai skala serang

$\mathrm{n}=$ jumlah tanaman yang memiliki nilai $\mathrm{v}$ yang sama

$\mathrm{Z}=$ nilai katagori serangan tertinggi $(\mathrm{v}=4)$

$\mathrm{N}=$ jumlah tanaman yang yang diamati.

Penentu nilai skala serangan sebagai berikut :

0 = tidak ada serangan

$1=$ kerusakan lebih kecil atau sama dengan $25 \%$

$2=$ kerusakan lebih besar $25 \%$ dan lebih kecil sama dengan $50 \%$

$3=$ kerusakan lebih besar $50 \%$ dan lebih kecil sama dengan $75 \%$

$4=$ kerusakan lebih besar dari 75\%. (Butar butar, 2013) 


\section{HASIL DAN PEMBAHASAN}

\section{Tinggi Tamanan}

Hasil uji lanjut dengan uji Duncan terhadap tinggi tamanan mentimun umur 14, 21, dan 28 hst dapat dilihat pada Tabel 1:

Tabel 1. Rata-rata tinggi tamanan mentimun umur 14, 21, dan 28 hst yang dipengaruhi perlakuan jenis bahan pestisida nabati.

\begin{tabular}{llll}
\hline \multirow{2}{*}{ Jenis bahan pestisida Nabati } & \multicolumn{3}{c}{ Tinggi Tanaman (cm) } \\
\cline { 2 - 4 } & $14 \mathrm{hst}$ & $21 \mathrm{hst}$ & $28 \mathrm{hst}$ \\
\hline P3 = Ekstrak Daun Pepaya dan Lamtoro & $28,00 \mathrm{a}$ & $85,42 \mathrm{a}$ & $146,36 \mathrm{a}$ \\
P2 = Ekstrak Daun Lamtoro & $27,44 \mathrm{~b}$ & $84,38 \mathrm{~b}$ & $145,06 \mathrm{~b}$ \\
P1 = Ekstrak Daun Pepaya & $26,78 \mathrm{c}$ & $83,97 \mathrm{c}$ & $143,06 \mathrm{c}$ \\
P0 = Tanpa pestisida & $26,44 \mathrm{~d}$ & $83,51 \mathrm{~d}$ & $142,39 \mathrm{~d}$ \\
\hline
\end{tabular}

Keterangan: Rata-rata yang diikuti huruf yang sama pada kolom yang sama menunjukkan berbeda tidak nyata pada uji DMRT taraf $5 \%$.

Tabel 1. Menunjukkan bahwa pengaruh jenis bahan pestisida nabati berbeda sangat nyata terhadap variabel tinggi tanaman umur 14, 21, dan 28 hst. Pada uji jarak berganda Duncan menunjukkan bahwa semua perlakuan antara P0 (Tanpa pestisida), P1 (Ekstrak Daun Pepaya), P2 (Ekstrak Daun Lamtoro), P3 (Ekstrak Daun Pepaya danLamtoro), saling berbeda nyata. Jenis bahan pestisida nabati pada umur 14 hst, perlakuan P3 (Ekstrak Daun Pepaya dan Lamtoro) mampu menghasilkan tinggi tanaman terbaik dengan rata-rata $28 \mathrm{~cm}$. Untuk jenis bahan pestisida nabati pada umur $21 \mathrm{hst}$, perlakuan P3 (Ekstrak Daun Pepaya dan Lamtoro) mampu menghasilkan tinggi tanaman terbaik dengan rata-rata $85,42 \mathrm{~cm}$. Dan jenis bahan pestisida nabati pada umur $28 \mathrm{hst}$, perlakuan P3 (Ekstrak Daun Pepaya dan Lamtoro) mampu menghasilkan tinggi tanaman terbaik dengan rata-rata $146,36 \mathrm{~cm}$.

Hasil analisis ragam tinggi tamanan mentimun umur 14, 21, dan 28 hst menunjukkan bahwa perlakuan pupuk cair green tonik berbeda sangat nyata (Tabel 1). Hasil uji lanjut dengan uji Duncan terhadap tinggi tamanan mentimun umur 14, 21, dan 28hst dapat dilihat pada Tabel 2:

Tabel 2. Rata-rata tinggi tamanan mentimun umur 14, 21, dan 28 hst yang dipengaruhi perlakuan pupuk cair green tonik.

\begin{tabular}{lrrr}
\hline \multirow{2}{*}{ Pupuk Cair Green Tonik } & \multicolumn{3}{c}{ Tinggi Tanaman (cm) } \\
\cline { 2 - 4 } & $14 \mathrm{hst}$ & $21 \mathrm{hst}$ & $28 \mathrm{hst}$ \\
\hline G3 = 14 dan 28 hst & $28,25 \mathrm{a}$ & $85,13 \mathrm{a}$ & $145,44 \mathrm{a}$ \\
$\mathrm{G} 2=7$ dan $14 \mathrm{hst}$ & $27,33 \mathrm{~b}$ & $84,19 \mathrm{~b}$ & $144,29 \mathrm{~b}$ \\
G1 $=$ Tanpa pestisida & $25,92 \mathrm{c}$ & $83,64 \mathrm{c}$ & $142,92 \mathrm{c}$ \\
\hline
\end{tabular}

Keterangan: Rata-rata yang diikuti huruf yang sama pada kolom yang sama menunjukkan berbeda tidak nyata pada uji DMRT taraf 5\%. 
Tabel 2. Menunjukkan bahwa perlakuan pupuk cair green tonik berbeda sangat nyata terhadap variabel tinggi tanaman umur 14, 21, dan 28hst. Pada uji jarak berganda Duncan menunjukkan bahwa semua perlakuan antaraG1 (Tanpa pestisida), G2 (7hari dan 14 hari) dan G3 (14 dan 28 hst), saling berbeda nyata. Perlakuan pupuk cair green tonik pada umur 14 hst, perlakuan G3 (14 dan 28 hst) mampu menghasilkan tinggi tanaman terbaik dengan rata-rata $28,25 \mathrm{~cm}$. Untuk perlakuan pupuk cair green tonik pada umur 21 hst, perlakuan G3 (14 dan 28 hst) mampu menghasilkan tinggi tanaman terbaik dengan rata-rata $85,13 \mathrm{~cm}$. Dan perlakuan pupuk cair green tonik pada umur 28 hst, perlakuan G3 (14 dan 28 hst) mampu menghasilkan tinggi tanaman terbaik dengan rata-rata 145,44 cm.

\section{Jumlah Buah}

Hasil uji lanjut Duncan terhadap jumlah buah dapat dilihat pada Tabel 2 berikut ini.

Tabel 2. Rata-rata jumlah buah mentimun yang dipengaruhi perlakuan jenis bahan pestisida nabati.

\begin{tabular}{cc} 
Jenis bahan pestisida Nabati & Jumlah Buah (buah) \\
\hline $\mathrm{P} 1=$ Ekstrak Daun Pepaya & $15,53 \mathrm{a}$ \\
$\mathrm{P} 2=$ Ekstrak Daun Lamtoro & $14,38 \mathrm{~b}$ \\
$\mathrm{P} 3=$ & $14,19 \mathrm{c}$ \\
$\mathrm{P} 0=$ & $13,51 \mathrm{~d}$ \\
\hline Keterangan : Ratrak Daun Pestisida & 13 ang diikuti huruf yang sama menunjukkan berbeda tidak nyata pada uji \\
& DMRT taraf 5\%.
\end{tabular}

Tabel 2. Menunjukkan bahwa pengaruh jenis bahan pestisida nabati berbeda sangat nyata terhadap variabel jumlah buah.Pada uji jarak berganda Duncan menunjukkan semua perlakuan antara P0 (Tanpa pestisida), P1 (Ekstrak Daun Pepaya), P2 (Ekstrak Daun Lamtoro) saling berbeda nyata, sedangkan perlakuan antara P3 (Ekstrak Daun Pepaya dan Lamtoro) dan P2 (Ekstrak Daun Lamtoro) bebeda tidak nyata. Jenis bahan pestisida nabati pada perlakuan P1 (Ekstrak Daun Pepaya) mampu menghasilkan jumlah buah terbaik dengan rata-rata 16 buah.

Hasil uji lanjut Duncan terhadap jumlah buah dapat dilihat pada Tabel 3 berikut ini. 
Tabel 3. Rata-rata jumlah buah yang dipengaruhi perlakuan pupuk cair green tonik.

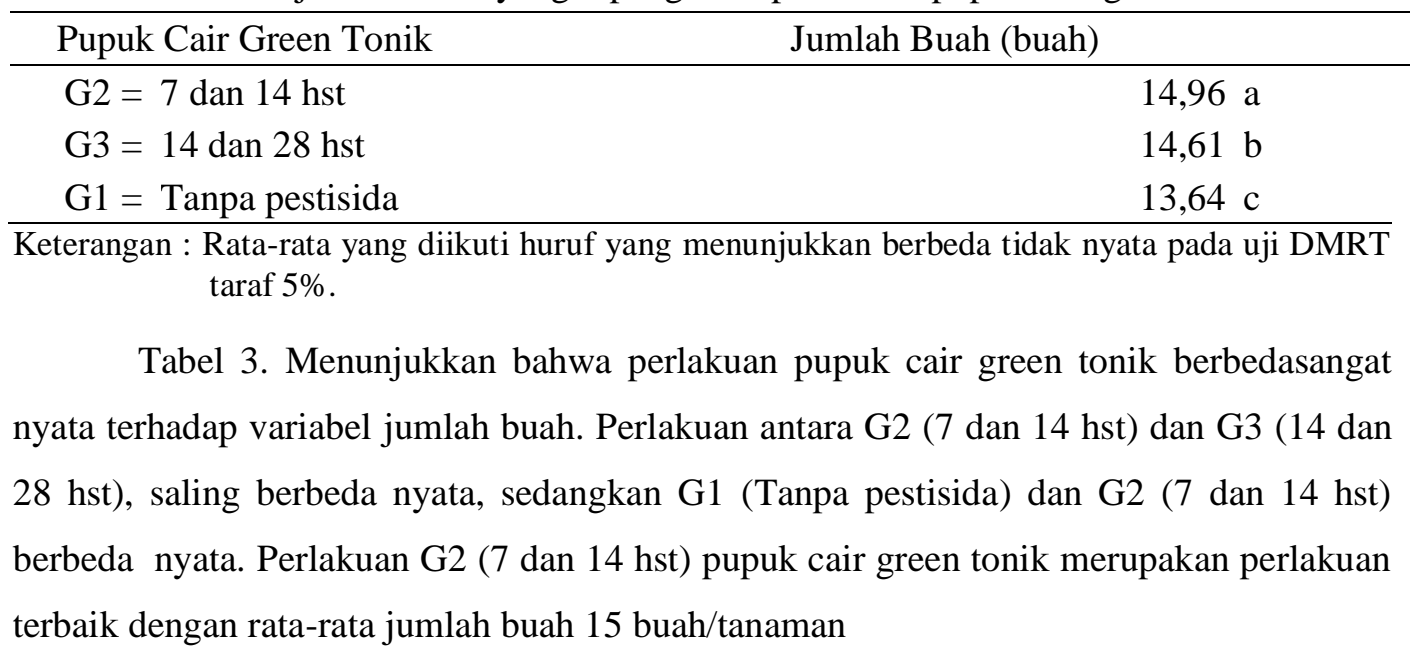

\section{Berat Buah}

Hasil uji lanjut Duncan terhadap berat buah dapat dilihat pada Tabel 4 berikut.

Tabel 4. Rata-rata berat buahmentimun yang dipengaruhi perlakuan jenis bahan pestisida nabati.

\begin{tabular}{lll}
\hline Jenis bahan pestisida Nabati & \multicolumn{2}{c}{ Berat Buah $(\mathrm{g})$} \\
\hline $\mathrm{P} 3=$ Ekstrak Daun Pepaya dan Lamtoro & 1435,22 & $\mathrm{a}$ \\
$\mathrm{P} 2=$ Ekstrak Daun Lamtoro & 1362,22 & $\mathrm{~b}$ \\
$\mathrm{P} 1=$ Ekstrak Daun Pepaya & 1293,61 & $\mathrm{c}$ \\
$\mathrm{P} 0=$ Tanpa pestisida & 1134,50 & $\mathrm{~d}$ \\
\hline
\end{tabular}

Keterangan : Rata-rata yang diikuti huruf yang menunjukkan berbeda tidak nyata pada uji DMRT taraf $5 \%$.

Tabel 4. Menunjukkan bahwa pengaruh jenis bahan pestisida nabati berbeda sangat nyata terhadap variabel berat buah.Pada uji jarak berganda Duncan menunjukkan bahwa semua perlakuan antaraP0 (Tanpa pestisida), P1 (Ekstrak Daun Pepaya), P2 (Ekstrak Daun Lamtoro), P3 (Ekstrak Daun Pepaya dan Lamtoro), saling berbeda nyata. Jenis bahan pestisida nabati pada perlakuan P3 (Ekstrak Daun Pepaya danLamtoro) mampu menghasilkan berat buah terbaik dengan rata-rata 1.435,22 g.

Hasil uji lanjut dengan uji Duncan terhadap berat buah dapat dilihat pada Tabel 5 berikut.

Tabel 5. Rata-rata berat buahmentimun yang dipengaruhi perlakuan pupuk cair green tonik.

\begin{tabular}{cc}
\hline Pupuk Cair Green Tonik & Berat Buah $(\mathrm{g})$ \\
\hline G3 $=14$ dan 28 hst & $1574,33 \mathrm{a}$ \\
G2 $=7$ dan 14 hst & $1414,38 \mathrm{~b}$ \\
G1 $=$ Tanpa pestisida & $930,46 \mathrm{c}$ \\
\hline
\end{tabular}

Keterangan: Rata-rata yang diikuti huruf yang menunjukkan berbeda tidak nyata pada uji DMRT taraf 5\%. 
Tabel 5. Menunjukkan bahwa perlakuan pupuk cair green tonik berbeda sangat nyata terhadap variabel berat buah. Pada uji jarak berganda Duncan menunjukkan bahwa semua perlakuan antara G1 (Tanpa pestisida), G2 (7 dan 14 hst) dan G3 (14 dan 28 hst), saling berbeda nyata.perlakuan pupuk cair green tonik perlakuan G3 (14 dan 28 hst) mampu menghasilkan berat buah terbaik dengan rata-rata $1.574,33 \mathrm{~g}$.

\section{Panjang Buah}

Hasil uji lanjut dengan uji Duncan terhadap panjang buah dapat dilihat pada Tabel 6 berikut

Tabel 6.Rata-rata panjang buah yang dipengaruhi perlakuan jenis bahan pestisida nabati.

\begin{tabular}{lllllll}
\hline Jenis bahan pestisida & \multicolumn{6}{c}{ Panjang Buah $(\mathrm{cm})$} \\
\cline { 2 - 7 } & Nabati & Panen 1 & Panen 2 & Panen 3 & Panen 4 & Panen 5 \\
\hline P3 & $8.89 \mathrm{a}$ & $10.90 \mathrm{a}$ & $11.04 \mathrm{a}$ & $11.11 \mathrm{a}$ & $9.92 \mathrm{a}$ \\
P2 & $8.78 \mathrm{~b}$ & $10.80 \mathrm{~b}$ & $10.80 \mathrm{~b}$ & $10.78 \mathrm{~b}$ & $9.80 \mathrm{~b}$ \\
P1 & $8.64 \mathrm{c}$ & $10.63 \mathrm{c}$ & $10.63 \mathrm{c}$ & $10.63 \mathrm{c}$ & $9.63 \mathrm{c}$ \\
P0 & $8.36 \mathrm{~d}$ & $10.31 \mathrm{~d}$ & $10.47 \mathrm{~d}$ & $10.24 \mathrm{~d}$ & $9.44 \mathrm{~d}$ \\
\hline
\end{tabular}

Keterangan: Rata-rata yang diikuti huruf yang sama pada kolong yang sama menunjukkan berbeda tidak nyata pada uji DMRT taraf 5\%.

Tabel 6. Menunjukkan bahwa pengaruh jenis bahan pestisida nabati berbeda sangat nyata terhadap variabel panjang buah. pada uji jarak berganda Duncan menunjukkan bahwa semua perlakuan antara P0 (Tanpa pestisida), P1 (Ekstrak Daun Pepaya), P2 (Ekstrak Daun Lamtoro), P3 (Ekstrak Daun Pepaya danLamtoro), saling berbeda nyata. Jenis bahan pestisida nabati pada panen pertama, perlakuan P3(Ekstrak Daun Pepaya danLamtoro) mampu menghasilkan panjang buah terbaik dengan rata-rata $8,89 \mathrm{~cm}$. Untuk jenis bahan pestisida nabati pada panen kedua, perlakuan P3 (Ekstrak Daun Pepaya danLamtoro) mampu menghasilkan panjang buah terbaik dengan rata-rata 10,9 cm. Jenis bahan pestisida nabati pada panen ketiga, perlakuan P3 (Ekstrak Daun Pepaya danLamtoro) mampu menghasilkan panjang buah terbaik dengan rata-rata 11,04 cm. Jenis bahan pestisida nabati pada panen keempat, perlakuan P3 (Ekstrak Daun Pepaya danLamtoro) mampu menghasilkan panjang buah terbaik dengan rata-rata 11,11cm. Dan jenis bahan pestisida nabati pada panen kelima, perlakuan P3 (Ekstrak Daun Pepaya danLamtoro) mampu menghasilkan panjang buah terbaik dengan rata-rata $9,92 \mathrm{~cm}$.

Hasil uji lanjut dengan uji Duncan terhadap panjang buah dapat dilihat pada Tabel 7 berikut. 
Tabel 7. Rata-rata panjang buah yang dipengaruhi perlakuan pupuk cair green tonik.

\begin{tabular}{|c|c|c|c|c|c|}
\hline \multirow{2}{*}{ Pupuk Cair Green Tonik } & \multicolumn{5}{|c|}{ Panjang Buah (cm) } \\
\hline & Panen 1 & Panen 2 & Panen 3 & Panen 4 & Panen 5 \\
\hline $\mathrm{G} 3=14$ & $8.85 \mathrm{a}$ & $10.87 \mathrm{a}$ & $10.91 \mathrm{a}$ & $10.90 \mathrm{a}$ & $9.93 \mathrm{a}$ \\
\hline $\mathrm{G} 2=7$ dan $14 \mathrm{hst}$ & $8.73 \mathrm{~b}$ & $10.74 \mathrm{~b}$ & $10.76 \mathrm{~b}$ & $10.76 \mathrm{~b}$ & $9.75 \mathrm{~b}$ \\
\hline G1 $=$ Tanpa pestisida & $8.43 \mathrm{c}$ & $10.37 \mathrm{c}$ & $10.54 \mathrm{c}$ & $10.41 \mathrm{c}$ & $9.42 \mathrm{c}$ \\
\hline
\end{tabular}

Keterangan: Rata-rata yang diikuti huruf yang sama pada kolong yang sama menunjukkan berbeda tidak nyata pada uji DMRT taraf 5\%.

Tabel 7. menunjukkan bahwa perlakuan pupuk cair green tonik berbeda sangat nyata terhadap variabel panjang buah.Pada uji jarak berganda Duncan menunjukkan bahwa semua perlakuan antaraG1 (Tanpa pestisida), G2 (7hari dan 14 hari) dan G3 (14 dan 28 hst), saling berbeda nyata.perlakuan pupuk cair green tonik pada panen pertama, perlakuan G3 (14 dan $28 \mathrm{hst}$ ) mampu menghasilkan panjang buah terbaik dengan ratarata 3,32 cm. Perlakuan pupuk cair green tonikpada panen kedua, perlakuan G3 (14 dan $28 \mathrm{hst}$ ) mampu menghasilkan panjang buah terbaik dengan rata-rata $4,43 \mathrm{~cm}$. Perlakuan pupuk cair green tonikpada panen ketiga, perlakuan G3 (14 dan 28 hst) mampu menghasilkan panjang buah terbaik dengan rata-rata $4,4 \mathrm{~cm}$. Perlakuan pupuk cair green tonikpada panen keempat, perlakuan G3 (14 dan 28 hst) mampu menghasilkan panjang buah terbaik dengan rata-rata 4,34 cm. Dan perlakuan pupuk cair green tonikpada panen kelima, perlakuan G3 (14 dan 28 hst) mampu menghasilkan panjang buah terbaik dengan rata-rata $3,44 \mathrm{~cm}$.

\section{Diameter Buah}

Hasil uji lanjut dengan uji Duncan terhadap diameter buah dapat dilihat pada Tabel 8 berikut. Menunjukkan bahwa pengaruh jenis bahan pestisida nabati berbeda sangat nyata terhadap variabel diameter buah. pada uji jarak berganda Duncan menunjukkan bahwa semua perlakuan antara P0 (Tanpa pestisida), P1 (Ekstrak Daun Pepaya), P2 (Ekstrak Daun Lamtoro), P3 (Ekstrak Daun Pepaya danLamtoro), saling berbeda nyata. Jenis bahan pestisida nabati pada panen pertama, perlakuan P3(Ekstrak Daun Pepaya danLamtoro) mampu menghasilkan diameter buah terbaik dengan rata-rata 3,38 cm. Untuk Jenis bahan pestisida nabati pada panen kedua, perlakuan P3 (Ekstrak Daun Pepaya danLamtoro) mampu menghasilkan diameter buah terbaik dengan rata-rata $4,51 \mathrm{~cm}$. Jenis bahan pestisida nabati pada panen ketiga, perlakuan P3 (Ekstrak Daun Pepaya danLamtoro) mampu menghasilkan diameter buah terbaik dengan rata-rata 4,49 cm. Jenis bahan pestisida nabati pada panen keempat, perlakuan P3 (Ekstrak Daun Pepaya danLamtoro) mampu menghasilkan diameter buah terbaik dengan rata-rata 4,4 cm. Dan jenis bahan pestisida nabati pada panen kelima, perlakuan P3 (Ekstrak Daun 
Pepaya dan Lamtoro) mampu menghasilkan diameter buah terbaik dengan rata-rata 3,43 $\mathrm{cm}$.

Tabel 8. Rata-rata diameter buah mentimun yang dipengaruhi perlakuan jenis bahan pestisida nabati.

\begin{tabular}{crrrrr}
\hline Jenis bahan pestisida & \multicolumn{6}{c}{ Diameter Buah $(\mathrm{cm})$} \\
\cline { 2 - 7 } Nabati & Panen 1 & Panen 2 & Panen 3 & Panen 4 & Panen 5 \\
\hline P3 & $3,38 \mathrm{a}$ & $4,51 \mathrm{a}$ & $4,49 \mathrm{a}$ & $4,40 \mathrm{a}$ & $3,43 \mathrm{a}$ \\
P2 & $3,17 \mathrm{~b}$ & $4,28 \mathrm{~b}$ & $4,17 \mathrm{~b}$ & $4,28 \mathrm{~b}$ & $3,31 \mathrm{~b}$ \\
P1 & $3,03 \mathrm{c}$ & $4,10 \mathrm{c}$ & $4,03 \mathrm{c}$ & $4,10 \mathrm{c}$ & $3,09 \mathrm{c}$ \\
P0 & $2,90 \mathrm{~d}$ & $3,98 \mathrm{~d}$ & $3,90 \mathrm{~d}$ & $3,98 \mathrm{~d}$ & $2,83 \mathrm{~d}$ \\
\hline
\end{tabular}

Keterangan : Rata-rata yang diikuti huruf yang sama pada kolom yang sama menunjukkan berbeda tidak nyata pada uji DMRT taraf 5\%.

Hasil uji lanjut dengan uji Duncan terhadap diameter buah dapat dilihat pada Tabel 9 berikut.

Tabel 9. Rata-rata diameter buahmentimun yang dipengaruhi perlakuan pupuk cair green tonik.

\begin{tabular}{crrrrr}
\hline \multirow{2}{*}{ Pupuk Cair Green Tonik } & \multicolumn{5}{c}{ Diameter Buah $(\mathrm{cm})$} \\
\cline { 2 - 6 } & Panen 1 & Panen 2 & Panen 3 & Panen 4 & Panen 5 \\
\hline G3 = 14 dan 28 hst & $3,32 \mathrm{a}$ & $4,43 \mathrm{a}$ & $4,40 \mathrm{a}$ & $4,34 \mathrm{a}$ & $3,44 \mathrm{a}$ \\
G2 = 7 dan 14 hst & $3,19 \mathrm{~b}$ & $4,24 \mathrm{~b}$ & $4,19 \mathrm{~b}$ & $4,24 \mathrm{~b}$ & $3,24 \mathrm{~b}$ \\
G1 = Tanpa pestisida & $2,85 \mathrm{c}$ & $3,99 \mathrm{c}$ & $3,85 \mathrm{c}$ & $3,99 \mathrm{c}$ & $2,82 \mathrm{c}$ \\
\hline
\end{tabular}

Keterangan: Rata-rata yang diikuti huruf yang sama pada kolom yang sama menunjukkan berbeda tidak nyata pada uji DMRT taraf 5\%.

Tabel 9. Menunjukkan bahwa perlakuan pupuk cair green tonik berbeda sangat nyata terhadap variabel diameter buah.Pada uji jarak berganda Duncan menunjukkan bahwa semua perlakuan antara G1 (Tanpa pestisida), G2 (7hari dan 14 hari) dan G3 (14 dan 28 hst), saling berbeda nyata.perlakuan pupuk cair green tonik pada panen pertama, perlakuan G3 (14 dan 28 hst) mampu menghasilkan diameter buah terbaik dengan ratarata 3,32 cm. Perlakuan pupuk cair green tonikpada panen kedua, perlakuan G3 (14 dan $28 \mathrm{hst}$ ) mampu menghasilkan diameter buah terbaik dengan rata-rata $4,43 \mathrm{~cm}$. Perlakuan pupuk cair green tonikpada panen ketiga, perlakuan G3 (14 dan 28 hst) mampu menghasilkan diameter buah terbaik dengan rata-rata $4,4 \mathrm{~cm}$. Perlakuan pupuk cair green tonikpada panen keempat, perlakuan G3 (14 dan 28 hst) mampu menghasilkan diameter buah terbaik dengan rata-rata 4,34 cm. Dan perlakuan pupuk cair green tonikpada panen kelima, perlakuan G3 (14 dan 28 hst) mampu menghasilkan diameter buah terbaik dengan rata-rata $3,44 \mathrm{~cm}$. 


\section{Jumlah Buah Sehat}

Hasil uji lanjut dengan uji Duncan terhadap jumlah buah sehat dapat dilihat pada Tabel 10 berikut.

Tabel 10. Rata-rata jumlah buah sehat mentimun yang dipengaruhi perlakuan jenis bahan pestisida nabati.

\begin{tabular}{cc}
\hline Jenis bahan pestisida Nabati & $\begin{array}{c}\text { Jumlah Buah Sehat } \\
\text { (buah) }\end{array}$ \\
\hline P3 = Ekstrak Daun Pepaya dan Lamtoro & $43.67 \quad \mathrm{a}$ \\
$\mathrm{P} 2=$ Ekstrak Daun Lamtoro & $41.89 \mathrm{~b}$ \\
$\mathrm{P} 1=$ Ekstrak Daun Pepaya & $40.11 \mathrm{c}$ \\
$\mathrm{P} 0=$ Tanpa pestisida & $39.00 \quad \mathrm{~d}$ \\
\hline Keterangan : Rata-rata yang diikuti huruf yang menunjukkan berbeda tidak nyata pada uji DMRT \\
taraf 5\%.
\end{tabular}

Tabel 10. Menunjukkan bahwa pengaruh jenis bahan pestisida nabati berbeda sangat nyata terhadap variabel jumlah buah sehat.Pada uji jarak berganda Duncan menunjukkan bahwa semua perlakuan antaraP0 (Tanpa pestisida), P1 (Ekstrak Daun Pepaya), P2 (Ekstrak Daun Lamtoro), P3 (Ekstrak Daun Pepaya danLamtoro), saling berbeda nyata. Jenis bahan pestisida nabati pada perlakuan P3 (Ekstrak Daun Pepaya dan Lamtoro) mampu menghasilkan jumlah buah sehat terbaik dengan rata-rata 44 buah.

Hasil analisis ragam jumlah buah sehat menunjukkan bahwa perlakuan pupuk cair green tonik berbeda sangat nyata (Tabel 1). Hasil uji lanjut dengan uji Duncan terhadap jumlah buah sehat dapat dilihat pada Tabel 11:

Tabel 11. Rata-rata jumlah buah sehatmentimun yang dipengaruhi perlakuan pupuk cair green tonik.

\begin{tabular}{cc}
\hline Pupuk Cair Green Tonik & $\begin{array}{c}\text { Jumlah Buah Sehat } \\
\text { (buah) }\end{array}$ \\
\hline G3 $=14$ dan 28 hst & $42.83 \mathrm{a}$ \\
G2 $=7$ dan 14 hst & $41.58 \mathrm{~b}$ \\
G1 $=$ Tanpa pestisida & $39.08 \mathrm{c}$ \\
\hline
\end{tabular}

Keterangan : Rata-rata yang diikuti huruf yang menunjukkan berbeda tidak nyata pada uji DMRT taraf $5 \%$.

Tabel 11. Menunjukkan bahwa perlakuan pupuk cair green tonik berbeda sangat nyata terhadap variabel jumlah buah sehat.Pada uji jarak berganda Duncan menunjukkan bahwa semua perlakuan antaraG1 (Tanpa pestisida), G2 (7 dan 14 hst) dan G3 (14 dan 28 hst), saling berbeda nyata.perlakuanpupuk cair green tonik perlakuan G3 (14 dan 28 hst) mampu menghasilkan jumlah buah sehat terbaik dengan rata-rata 43 buah. 


\section{Intensitas Serangan}

Hasil uji lanjut dengan uji Duncan terhadap intensitas seranganumur 7, 14, dan 21 hst dapat dilihat pada Tabel 12 berikut.

Tabel 12. Rata-rata intensitas serangan mentimun umur 7, 14, dan 21 hst yang dipengaruhi perlakuan jenis bahan pestisida nabati.

\begin{tabular}{cccc}
\hline \multirow{2}{*}{ Jenis bahan pestisida Nabati } & \multicolumn{3}{c}{ Intensitas Serangan (\%) } \\
\cline { 2 - 5 } & $7 \mathrm{hst}$ & $14 \mathrm{hst}$ & $21 \mathrm{hst}$ \\
\hline P0 & $13,44 \mathrm{a}$ & $12,33 \mathrm{a}$ & $12,22 \mathrm{a}$ \\
P1 & $12,89 \mathrm{~b}$ & $10,44 \mathrm{~d}$ & $11,67 \mathrm{~b}$ \\
P2 & $11,56 \mathrm{~d}$ & $11,78 \mathrm{~b}$ & $11,22 \mathrm{c}$ \\
P3 & $12,44 \mathrm{c}$ & $11,44 \mathrm{c}$ & $10,11 \mathrm{~d}$ \\
\hline
\end{tabular}

Keterangan: Rata-rata yang diikuti huruf yang sama pada kolom yang sama menunjukkan berbeda tidak nyata pada uji DMRT taraf 5\%.

Tabel 12. Menunjukkan bahwa pengaruh jenis bahan pestisida nabati berbeda sangat nyata terhadap variabel intensitas seranganumur 7, 14, dan 21 hst. Pada uji jarak berganda Duncan menunjukkan bahwa semua perlakuan antaraP0(Tanpa pestisida), P1 (Ekstrak Daun Pepaya), P2 (Ekstrak Daun Lamtoro), P3 (Ekstrak DaunPepaya danLamtoro), saling berbeda nyata. Jenis bahan pestisida nabati pada umur 7 hst, perlakuan P2 (Ekstrak Daun Lamtoro) mampu menghasilkan intensitas serangan terbaik dengan rata-rata $11,56 \%$. Jenis bahan pestisida nabati pada umur 14 hst, perlakuan P1 (Ekstrak Daun Pepaya) mampu menghasilkan intensitas serangan terbaik dengan rata-rata 10,44\%. Dan jenis bahan pestisida nabati pada umur 21 hst, perlakuan P3 (Ekstrak Daun Pepaya danLamtoro) mampu menghasilkan intensitas serangan terbaik dengan rata-rata $10,11 \%$.

\section{KESIMPULAN}

Berdasarkan hasil penelitian tentang respon tanaman mentimun (Cucumis sativus L) terhadap jenis bahan pestisida nabati dan pupuk cair green tonik, maka dapat disimpulkan bahwa:

1. Jenis bahan pestisida nabati memberikan pengaruh nyata terhadap semua pertumbuhan, hasil dan intensitas serangan OPT, perlakuan P3 (Ekstrak Daun Pepaya dan Daun Lamtoro) mampu memberikan hasil terbaik tinggi tamanan, berat buah, panjang buah, diameter buah, jumlah buah sehat dan dapat menekan intensitas serangan OPT.

2. Perlakuan pupuk cair green tonikmemberikan pengaruh nyata terhadap pertumbuhan, hasil tamanan mentimun perlakuan G3 (14 dan 28 hst) mampu memberikan hasil 
terbaik pada tinggi tanaman, berat buah, panjang buah, diameter buah, jumlah buah sehat dan umur berbunga pertumbuhan dan hasil tanaman mentimun.

3. Perlakuan interaksi jenis bahan pestisida nabati dan pupuk cair green tonik tidak memberikan pengaruh nyata terhadap semua variabel pengamatan.

\section{DAFTAR PUSTAKA}

Anonim, 2007. Pestisida Nabati. www. Google.Liptan-pestisida.Doc. 2007.Diakses bulan maret 2008.

Anonim.2012a. Makalah Penelitian Pestisida Alami Dari Daun Pepaya. http://sulistiyanto21.blogspot.com/2012/11/makalah-penelitian-pestisida-alamidari.html (Diakses tanggal 1 september 2014).

Anomim.2013c. karya tulis pemanfaatan ekstrak daun pepaya sebagai pestisida alami yang ramah lingkungan. http://tonorip.blogspot.com/2013/06/karya-tulis-ekstrakdaun.html (Diakses tanggal 20 juli 2015).

Brown H. 2003. Common insect pests of curcubits. Agnote, 149: 39-45.

CABI.Center for agriculture and bioscience International. 2005. Corp protection compendium 2005 (CD-ROM). Wallingford, UK: CAB International.

Djojosumarto, P,.2008, Teknik Aplikasi Pestisida Pertanian, Kanisius, Yogyakarta.

Hodiyah, 2015, Biopostisida sebagai penendalian organisme penganggu tanaman yang ramah lingkungan.Jurnal EMBRIYO 6(1): 88-95.

Marschel, H,. 1995. Mineral Nutrition of Higher Plants. Second Edition. Academic Press, London.

Mossler MA, Larson BC, Nesheim ON. 2007. Florida crop/pest management profiles: celery. Plant Pathology Dapertment Document CIR 1235. Food Science and Human Nutrition Dapetment, Florida Cooperative Extension Sevice, Institute of Food and Agricultural Scciences, University of Florida.

Purwanto I. 2007.Mengenai Lebih Dekat Leguminoseae. Yogyakarta. Penerbit Kanisius

Rahmi, A. Dan Jumiati. 2007. Pengaruh Konsentrasi dan Waktu Penyemprotan Pupuk Organik Cair. Fakultas Pertanian - Universitas Udayana.

Rukmana, R. 1994. Budidaya Mentimun. Penerbit Kanisius, Yogyakarta. Hal, 5-8.

Sumpena, U. 2001.Budidaya Mentimun Intensif dengan Mulsa Secara Tumpang Gilir.Jakarta : Penebar Swadaya. 